\title{
KEMAMPUAN MENULIS TEKS NASKAH DRAMA SISWA KELAS VIII SMP NEGERI 18 KOTA BENGKULU
}

\author{
Devia Oktari, Agus Joko Purwadi, dan Amrizal \\ Program Studi Pendidikan Bahasa Indonesia \\ Jurusan Pendidikan Bahasa dan Seni \\ FKIP Universitas Bengkulu \\ Deviaoktarii@gmail.com
}

\begin{abstract}
Abstrak
Tujuan penelitian ini untuk mendeskripsikan kemampuan menulis teks naskah drama siswa kelas VIII SMP Negeri 18 Kota Bengkulu. Kemampuan menulis teks naskah drama siswa kelas VIII ini akan dinilai dari enam aspek, yaitu: plot atau kerangka cerita, penokohan dan perwatakan, dialog dan teks samping, setting/latar, tema, dan amanat. Metode penelitian yang digunakan yaitu deskriptif dengan pendekatan kuantitatif. Pengambilan sampel dilakukan dengan teknik random sampling (sampel acak). Teknik analisis data yang digunakan dalam penelitian yaitu statistik sederhana dengan menghitung nilai rata-rata dari setiap aspek, serta mencari skor akhir. Hasil penelitian ini dapat dikemukakan bahwa: 1). Rata-rata kemampuan menulis teks naskah drama siswa yang dilihat dari aspek plot atau kerangka cerita adalah 19,46 berkategori (baik). 2). Rata-rata kemampuan menulis teks naskah drama siswa dilihat dari aspek penokohan dan perwatakan adalah 11,77 berkategori (baik). 3). Rata-rata kemampuan menulis teks naskah drama siswa dilihat dari aspek dialog dan teks samping adalah 18,6 berkategori (baik). 4). Rata-rata kemampuan menulis teks naskah drama siswa dilihat dari aspek setting/latar adalah 8 berkategori (baik). 5). Rata-rata kemampuan menulis teks naskah drama siswa dilihat dari aspek tema atau nada dasar adalah 7,97 berkategori (baik). 6). Rata-rata kemampuan menulis teks naskah drama siswa dilihat dari aspek amanat adalah 10,8 berkategori (baik). 7). Rata-rata nilai akhir kemampuan menulis teks naskah drama siswa kelas VIII SMP Negeri 18 Kota Bengkulu adalah 76,6 tergolong berkategori (baik). Kesimpulan dari penelitian ini adalah bahwa siswa kelas VIII SMP Negeri 18 Kota Bengkulu telah dapat menulis teks naskah drama dengan baik. Meskipun masih ada beberapa siswa dalam menulis dinyatakan cukup, namun secara keseluruhan para siswa sudah dapat menulis teks naskah drama dengan baik.
\end{abstract}

Kata kunci: kemampuan, menulis, naskah drama.

\begin{abstract}
Abstrak
The purpose of this study was to describe the ability to write drama script texts of class VIII students of SMP Negeri 18 Kota Bengkulu. The ability to write drama script texts of class VIII students will be assessed from six aspects, namely: plot or story frame, characterization and character, dialogue and side text, setting / setting, theme, and mandate. The research method used is descriptive with a quantitative approach. Sampling is done by random sampling technique. The data analysis technique used in the research is simple statistics by calculating the average value of each aspect, and looking for the final score. The results of this study can be stated that: 1). The average
\end{abstract}


ability to write student drama script texts seen from the aspect of the plot or storyline is 19.46 categorized (good). 2). The average ability of writing drama script texts of students seen from the characterization aspect and rank is 11.77 categorized (good). 3). The average ability of writing drama script texts in terms of dialogue and side text is 18.6 categories (good). 4). The average ability to write student drama script texts in terms of setting / background is 8 categories (good). 5). The average ability to write drama script texts of students seen from the aspect of the theme or basic tone is 7.97 categorized (good). 6). The average ability to write student drama script texts seen from the mandate aspect is 10.8 categories (good). 7). The average final grade of the ability to write drama script texts for class VIII students of SMP Negeri 18 Kota Bengkulu is 76.6 categorized as (good). The conclusion of this study is that the eighth grade students of SMP Negeri 18 Kota Bengkulu have been able to write drama texts well. Even though there are still a few students in writing it is declared sufficient, but overall the students have been able to write drama text well.

Keywords: ability, writing, drama script.

\section{PENDAHULUAN}

Tujuan pembelajaran Bahasa Indonesia di sekolah melatih aspek keterampilan berbahasa, yaitu: menyimak, berbicara, membaca dan menulis. Penguasaan empat keterampilan yang diajarkan tersebut merupakan keterampilan dasar yang digunakan sebagai modal bagi pengembangan diri peserta didik dalam menempuh pendidikan ke sekolah yang lebih tinggi.

Keempat keterampilan tersebut saling berkaitan. Namun, keterampilan menulis merupakan keterampilan yang paling tinggi tingkatannya di antara keterampilan berbahasa lainnya, karena dalam menulis seseorang membutuhkan ide atau gagasan yang harus disusun dan dipikirkan agar menjadi suatu tulisan yang baik. Hal tersebut sesuai dengan pendapat Dalman (2013:3) yang menyatakan menulis sebagai salah satu keterampilan berbahasa merupakan aktivitas untuk mengungkapkan ide, gagasan, pikiran, pengetahuan dan pengalaman dalam bentuk bahasa tulis sebagai medianya.

Menulis merupakan suatu usaha untuk mengungkapkan ide dan gagasan yang disusun secara sistematis agar mudah dimengerti dan dipahami oleh pembaca. Tarigan (2008:22) mengemukakan menulis ialah menurunkan atau melukiskan lambang-lambang grafik yang menggambarkan suatu bahasa yang dipahami oleh seseorang, sehingga orang lain dapat membaca lambang-lambang grafik tersebut kalau mereka memahami bahasa dan grafik itu.

Keterampilan menulis haruslah terus dilatih agar peserta didik mampu berpikir kritis dalam menuangkan ide, gagasan, dan pendapat secara tertulis, terutama dalam mata pelajaran bahasa Indonesia. Sebagai keterampilan berbahasa yang paling tinggi tingkatannya, dalam keterampilan menulis diperlukan strategi dan latihan yang tepat.

Salah satu keterampilan menulis yang ada dalam pembelajaran Bahasa Indonesia yaitu keterampilan menulis teks naskah drama. Keterampilan menulis teks naskah drama terdapat pada Kompetensi Dasar di SMP kelas VIII semester genap. Menulis drama merupakan keterampilan yang membutuhkan ide-ide kreatif karena dalam menulis teks naskah drama penulis akan memunculkan dialog, penokohan, 
alur, tema, latar, dan amanat yang memberikan pesan dan kesan kepada pembaca. Istilah drama, dihadapkan dengan dua kemungkinan, yaitu drama naskah dan dan drama pentas. Keduanya bersumber pada drama naskah (Waluyo, 2001:2). Dalam penelitian ini, peneliti akan meneliti kemampuan menulis teks naskah drama siswa.

Putra (2012: 25) mengemukakan naskah drama memiliki peranan yang penting dalam pementasan drama karena naskah drama merupakan karangan yang berisi cerita atau lakon. Di dalam naskah drama tertulis nama-nama tokoh, dialog para tokoh yang disertai penggambaran ekspresi, dan setting panggung yang diperlukan.

Waluyo (2002:7-29) mengungkapkan bahwa terdapat unsur pembangun teks naskah drama yang dibagi menjadi 6 aspek, yaitu: (1) plot atau kerangka cerita, (2) penokohan atau perwatakan, (3) dialog dan teks samping, (4) setting/latar, (5) tema, dan (6) amanat atau pesan pengarang. Peneliti akan melakukan penelitian dari enam aspek pembangun teks di atas.

Berdasarkan fakta, dalam menulis karya sastra salah satunya drama, seseorang mengalami kesulitan dalam menuangkan ide atau gagasan yang akan dituliskan (Achmad, 2016:9). Selain itu, berdasarkan observasi awal peneliti, dalam menulis peserta didik kurang memiliki minat dan motivasi karena pelajaran menulis dianggap membosankan bagi peserta didik. Seorang guru dapat memilih pendekatan, strategi, dan metode yang tepat untuk mengatasi kesulitan yang dialami oleh peseta didik. Dengan demikian materi yang disampaikan dalam proses belajar mengajar akan berjalan sesuai dengan tujuan yang ingin dicapai.

Menjadi seorang guru yang kreatif bukanlah suatu hal yang mudah. Semuanya tergantung dengan kompetensi yang dimiliki guru, seorang guru harus memiliki kompetensi pedagogik, kompetensi profesional, dan kompetensi kepribadian agar peserta didik menjadi lebih kreatif, inovatif dan kemampuan menulis siswa dalam menulis teks naskah drama menjadi lebih baik. Guru perlu mencari upaya sesuai dengan kondisi peserta didik, materi, bahan ajar, dan tujuan pembelajaran. Dari upaya yang dilakukan oleh guru diharapkan peserta didik memiliki kemampuan menulis teks naskah drama.

Penelitian tentang pembelajaran dalam menulis drama pernah dilakukan oleh Yundi Fitrah (2016) dengan judul Kemampuan Menulis Naskah Drama Siswa kelas VIII C SMP Negeri 23 Kota Jambi Tahun Ajaran 2016/2017. Hasil penelitian tersebut adalah kemampuan menulis naskah drama siswa kelas VIII SMP Negeri 23 Kota Jambi tahun ajaran 2016/2017 tergolong kategori cukup mampu.

Berdasarkan latar belakang tersebut, maka peneliti ingin melakukan penelitian mengenai Keimampuan Menulis Teks Naskah Drama Siswa Kelas VIII SMP Negeri 18 Kota Bengkulu.

\section{METODE}

Penelitian ini menggunakan metode deskriptif dengan pendekatan kuantitatif yaitu secara apa adanya sesuai dengan fakta yang ada mengenai kemampuan menulis teks naskah drama

Penelitian ini dilakukan di kelas VIII SMP Negeri 18 Kota Bengkulu yang terletak di Jalan Ks. Tubun Lingkar Barat Kota Bengkulu. Waktu penelitian dilakukan pada semester genap tahun ajaran 2017/2018.

Pada penelitian ini, pengambilan sampel dilakukan dengan teknik random sampling. Peneliti mengambil sampel secara homogen sebesar $15 \%$ dari jumlah populasi. Populasi dalam penelitian ini sebanyak 323 orang siswa, jika diambil 15\% secara acak maka jumlah sampelnya sebanyak 48 orang siswa. Teknik yang digunakan dalam pengumpulan data terdiri 
atas teknik tes. Tes adalah alat ukur yang diberikan. Data yang dikumpulkan dalam penelitian ini berbentuk tugas dari hasil tes menulis teks naskah drama siswa. Instrumen dalam penelitian kuantitatif dapat berupa tes, pedoman wawancara, pedoman observasi dan kuesioner.

Instrumen penelitian ini berbentuk tes. Tes berisi petunjuk menyusun teks naskah drama. Setelah data dari seluruh responden atau sumber data lain terkumpul, maka peneliti malakukan analisis data.

Langkah-langkah menganalisis dilakukan dengan teknik sebagai berikut.

1. Membaca seluruh teks naskah drama yang ditulis siswa.

2. Memberikan skor atau nilai pada tiaptiap teks naskah drama yang ditulis oleh siswa. Penilaian dilakukan oleh dua orang yaitu peneliti sendiri sebagai penilai satu dan guru Bahasa Indonesia sebagai penilai dua.

3. Menggabungkan nilai dari penilai satu dan penilai dua.

4. Menghitung rata-rata kemampuan menulis teks naskah drama siswa dengan rumus sebagai berikut :

$$
\mathrm{M}=\frac{\sum x}{N}
$$

Keterangan:

$$
\begin{aligned}
& \mathbf{M} \text { : Rata-rata nilai } \\
& \mathbf{\Sigma x} \text { : Jumlah nilai } \\
& \mathbf{N} \text { : Jumlah siswa }
\end{aligned}
$$

5. Menentukan kualifikasi kemampuan menulis teks naskah drama siswa dengan interval skala.

\begin{tabular}{|c|c|c|}
\hline No. & Rentang Skor & Kualifikasi \\
\hline 1. & $85-100$ & Sangat Baik \\
\hline 2. & $75-84$ & Baik \\
\hline 3. & $60-74$ & Cukup \\
\hline 4. & $40-59$ & Kurang \\
\hline 5. & $1-39$ & Sangat Kurang \\
\hline
\end{tabular}

\section{HASIL DAN PEMBAHASAN}

Berdasarkan hasil penelitian yang sudah dilakukan maka diperoleh hasil penelitian terdiri atas enam aspek sebagai berikut:
1. Kemampuan menulis teks naskah drama dari aspek plot atau kerangka cerita.

2. Kemampuan menulis teks naskah drama siswa dari aspek penokohan dan perwatakan.

3. Kemampuan menulis teks naskah drama siswa dari aspek dialog dan teks samping.

4. Kemampuan menulis teks naskah drama siswa dari aspek setting atau latar.

5. Kemampuan menulis teks naskah drama siswa dari aspek tema.

6. Kemampuan menulis teks naskah drama siswa dari aspek amanat atau pesan pengarang.

Kemampuan menulis teks naskah drama siswa kelas VIII SMP Negeri 18 Kota Bengkulu tahun ajaran 2017/2018 dikategorikan baik. Hal ini dikarenakan nilai rata-rata akhir yang diperoleh adalah sebesar 76,6. Hasil nilai rata-rata tersebut jika dikonversikan dengan perhitungan skala lima berada pada rentang $75-84$ dan termasuk ke dalam kategori baik.

\section{Kemampuan Menulis Teks Naskah Drama Siswa Kelas VIII SMP Negeri 18 Kota Bengkulu}

\begin{tabular}{|l|l|c|c|}
\hline No. & \multicolumn{1}{|c|}{$\begin{array}{c}\text { Aspek yang } \\
\text { Dinilai }\end{array}$} & $\begin{array}{c}\text { Rata-rata } \\
\text { Nilai }\end{array}$ & Kategori \\
\hline 1. & $\begin{array}{l}\text { Plot atau } \\
\text { Kerangka Cerita }\end{array}$ & 19,46 & Baik \\
\hline 2. & $\begin{array}{l}\text { Penokohan dan } \\
\text { Kesesuaian Tokoh }\end{array}$ & 11,77 & Baik \\
\hline 3. & $\begin{array}{l}\text { Dialog dan Teks } \\
\text { Samping }\end{array}$ & 18,6 & Baik \\
\hline 4. & Setting atau Latar & 8 & Baik \\
\hline 5. & Tema & 7,97 & Baik \\
\hline 6. & $\begin{array}{l}\text { Amanat atau } \\
\text { Pesan Pengarang }\end{array}$ & 10,8 & Baik \\
\hline & \multicolumn{2}{|l}{} & Baik \\
\hline
\end{tabular}

Berdasarkan tabel di atas dapat diperoleh nilai akhir kemampuan menulis teks naskah drama siswa kelas VIII SMP Negeri 18 Kota Bengkulu ialah 76,6, 
sehingga jika dimasukkan ke dalam rentang nilai skala lima dapat dikatakan bahwa kemampuan menulis teks naskah drama siswa kelas VIII SMP Negeri 18 Kota Bengkulu dikategorikan baik, karena berada pada rentang nilai 75-84. Selain itu, nilai yang diperoleh siswa beraneka ragam.

Jika penilaian tersebut dimasukkan dalam interval skala lima untuk perhitungan jumlah frekuensi, adalah sebagai berikut.

\section{Frekuensi Nilai Kemampuan Menulis Teks Naskah Drama Siswa Kelas VIII SMP Negeri 18 Kota Bengkulu}

\begin{tabular}{|c|c|c|}
\hline Rentang Nilai & Frekuensi & $\begin{array}{c}\text { Kategori } \\
\text { Penilaian }\end{array}$ \\
\hline $85-100$ & 7 & Sangat Baik \\
\hline $75-84$ & 26 & Baik \\
\hline $60-74$ & 11 & Cukup \\
\hline $40-59$ & 4 & Kurang \\
\hline $0-39$ & 0 & Sangat Kurang \\
\hline
\end{tabular}

Berdasarkan hasil perhitungan pada tabel di atas, maka dapat diketahui bahwa kemampuan menulis teks naskah drama siswa kelas VIII SMP Negeri 18 Kota Bengkulu yang dilihat dari semua aspek menulis teks naskah drama, terbagi atas 7 siswa termasuk ke dalam kategori sangat baik, 26 siswa termasuk ke dalam kategori baik, 11 siswa termasuk ke dalam kategori cukup, 4 siswa termasuk ke kategori kurang dan kategori sangat kurang tidak dijumpai.

Berdasarkan frekuensi di atas, selanjutnya dapat dibuat histogram kemampuan menulis teks naskah drama siswa kelas VIII SMP Negeri 18 Kota Bengkulu sebagai berikut.

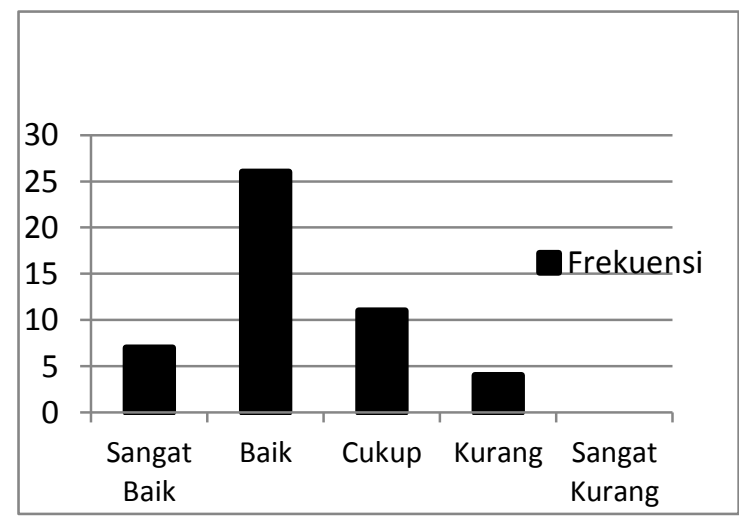

Berikut adalah pembahasan data kemampuan menulis teks naskah drama siswa kelas VIII SMP Negeri 18 Kota Bengkulu dinilai berdasarkan unsur pembangun teks naskah drama yang dibagi menjadi 6 aspek, yaitu: (1) plot atau kerangka cerita, (2) penokohan atau perwatakan, (3) dialog dan teks samping, (4) setting/latar, (5) tema, dan (6) amanat atau pesan pengarang.

\section{Kemampuan Menulis Teks Naskah Drama Siswa Kelas VIII SMP Negeri 18 Kota Bengkulu dari Aspek Plot atau Kerangka Cerita}

Plot merupakan jalinan cerita dari awal hingga akhir yang merupakan jalinan konflik antara dua tokoh yang berlawanan (Waluyo, 2002:8). Berdasarkan hasil analisis data, kemampuan menulis teks naskah drama siswa kelas VIII SMP Negeri 18 Kota Bengkulu dari aspek plot atau kerangka cerita dikategorikan baik karena rata-rata yang diperoleh sebesar 19,46. Jika dilihat pada rentang penilaian pada aspek plot atau kerangka cerita tersebut, termasuk ke dalam kategori baik karena terletak pada rentang nilai $16-20$.

Selain itu, dari hasil analisis data yang telah dilakukan pada aspek plot atau kerangka cerita, kebanyakan siswa sudah dapat menulis teks naskah drama dengan baik. Sesuai dengan kategori penilaian dalam aspek plot atau kerangka cerita, seperti penyajian plot mendukung jalinan cerita karena memiliki kelengkapan komponen eksposisi, komplikasi, klimaks, dan resolusi, disertai urutan cerita yang logis walaupun ada cerita yang terpotong. Hanya saja ada beberapa siswa yang terjadi kekurangan yaitu penyajian plot kurang mendukung jalinan cerita karena ada salah satu komponen yang tidak ada, disertai urutan cerita yang logis dan cerita yang terpotong 
2. Kemampuan Menulis Teks Naskah Drama Siswa Kelas VIII SMP Negeri 18 Kota Bengkulu dari Aspek Penokohan dan Perwatakan

Fungsi tokoh adalah untuk menghidupkan cerita dan menyampaikan amanat penulis (Yonny, 2014:35). Penokohan erat hubungannya dengan perwatakan. Susunan tokoh (drama persone) adalah daftar tokoh-tokoh yang beperan dalam drama itu. Berdasarkan hasil analisis data, kemampuan menulis teks naskah drama siswa kelas VIII SMP Negeri 18 Kota Bengkulu dari aspek penokohan dan perwatakan dikategorikan baik karena rata-rata yang diperoleh sebesar 11,77 . Jika dilihat pada rentang penilaian pada aspek penokohan dan perwatakan tersebut, termasuk ke dalam kategori baik karena terletak pada rentang nilai $10-12$.

Selain itu, dari hasil analisis data yang telah dilakukan pada aspek penokohan dan perwatakan kebanyakan siswa sudah dapat menulis teks naskah drama dengan baik. Sesuai dengan kategori penilaian dalam aspek penokohan dan perwatakan, seperti karakter tokoh digambarkan secara jelas dan penokohan menarik dalam menghidupkan jalan cerita. Hanya saja ada beberapa siswa yang terjadi kekurangan yaitu karakter tokoh digambarkan cukup jelas dan penokohan kurang menarik dalam menghidupkan jalan cerita.

\section{Kemampuan Menulis Teks Naskah} Drama Siswa Kelas VIII SMP Negeri 18 Kota Bengkulu dari Aspek Dialog dan Teks Samping

Ciri khas suatu drama adalah naskah itu berbentuk cakupan atau dialog. Berdasarkan hasil analisis data, kemampuan menulis teks naskah drama siswa kelas VIII SMP Negeri 18 Kota Bengkulu dari aspek dialog dan teks samping dikategorikan baik karena rata-rata yang diperoleh sebesar 18,6. Jika dilihat pada rentang penilaian pada aspek dialog dan teks samping tersebut, termasuk ke dalam kategori baik karena terletak pada rentang nilai 16-20.

Selain itu, dari hasil analisis data yang telah dilakukan pada aspek dialog dan teks samping kebanyakan siswa sudah dapat menulis teks naskah drama dengan baik. Sesuai dengan kategori penilaian dalam aspek dialog dan teks samping, seperti dialog yang digunakan sesuai dengan tiaptiap karakter tokoh, dikembangkan dengan ragam bahasa komunikatif, pilihan diksi cukup sesuai dengan alur yang dibuat dan memiliki teks samping. Hanya saja ada beberapa siswa yang terjadi kekurangan yaitu dialog yang digunakan kurang sesuai dengan tiap-tiap karakter tokoh dan tidak adanya teks samping.

\section{Kemampuan Menulis Teks Naskah Drama Siswa Kelas VIII SMP Negeri 18 Kota Bengkulu dari Aspek Setting atau Latar}

Berdasarkan hasil analisis data, kemampuan menulis teks naskah drama siswa kelas VIII SMP Negeri 18 Kota Bengkulu dari aspek setting atau latar dikategorikan baik karena rata-rata yang diperoleh sebesar 8. Jika dilihat pada rentang penilaian pada aspek setting atau latar tersebut, termasuk ke dalam kategori baik karena terletak pada rentang nilai 7 8.

Selain itu, dari hasil analisis data yang telah dilakukan pada aspek setting atau latar kebanyakan siswa sudah dapat menulis teks naskah drama dengan baik. Sesuai dengan kategori penilaian dalam aspek setting atau latar, seperti latar cerita dikembangkan dengan jelas dan sesuai dengan tema yang ditentukan. Hanya saja ada beberapa siswa yang terjadi kekurangan yaitu seperti latar cerita dikembangkan kurang jelas dan tidak sesuai dengan tema yang ditentukan. 


\section{Kemampuan Menulis Teks Naskah Drama Siswa Kelas VIII SMP Negeri 18 Kota Bengkulu dari Aspek Tema}

Tema adalah pokok persoalan yang diangkat dalam drama. Berdasarkan hasil analisis data, kemampuan menulis teks naskah drama siswa kelas VIII SMP Negeri 18 Kota Bengkulu dari tema dikategorikan baik karena rata-rata yang diperoleh sebesar 7,97. Jika dilihat pada rentang penilaian pada aspek tema tersebut, termasuk ke dalam kategori baik karena terletak pada rentang nilai $7-8$.

Selain itu, dari hasil analisis data yang telah dilakukan pada aspek tema kebanyakan siswa sudah dapat menulis teks naskah drama dengan baik. Sesuai dengan kategori penilaian dalam tema, isi cerita sesuai dengan tema yang telah ditentukan. Hanya saja ada beberapa siswa yang terjadi kekurangan yaitu isi cerita kurang sesuai dengan tema yang ditentukan.

\section{Kemampuan Menulis Teks Naskah Drama Siswa Kelas VIII SMP Negeri 18 Kota Bengkulu dari Aspek Amanat atau Pesan Pengarang}

Berdasarkan hasil analisis data, kemampuan menulis teks naskah drama siswa kelas VIII SMP Negeri 18 Kota Bengkulu dari amanat atau pesan pengarang dikategorikan baik karena ratarata yang diperoleh sebesar 10,8. Jika dilihat pada rentang penilaian pada aspek amanat atau pesan pengarang tersebut, termasuk ke dalam kategori baik karena terletak pada rentang nilai 10-12.

Selain itu, dari hasil analisis data yang telah dilakukan pada aspek amanat atau pesan pengarang kebanyakan siswa sudah dapat menulis teks naskah drama dengan baik. Sesuai dengan kategori penilaian dalam amanat atau pesan pengarang, seperti terdapat penyampaian amanat yang dapat dipetik dan sesuai dengan tema yang ditentukan. Hanya saja ada beberapa siswa yang terjadi kekurangan yaitu kurang adanya penyampaian amanat dan tidak sesuai dengan tema yang telah ditentukan.

\section{PENUTUP}

\section{Kesimpulan}

Berdasarkan hasil penelitian dan pembahasan dapat disimpulkan bahwa kemampuan menulis teks naskah drama siswa kelas VIII SMP Negeri 18 Kota Bengkulu tahun ajaran 2017/2018 berkategori baik. Hal ini dapat dilihat dari hasil penelitian tingkat kemampuan dengan nilai rata-rata yang diperoleh adalah sebesar 76,6. Nilai rata-rata tersebut jika dikonversikan dengan perhitungan skala lima berada pada rentang 75 - 84 dan termasuk dalam kategori baik.

Dengan kata lain, kemampuan menulis teks naskah drama siswa kelas VIII SMP Negeri 18 Kota Bengkulu tergolong baik. Hal ini membuktikan bahwa menulis teks naskah drama merupakan sebuah keterampilan yang dapat dilatih dan dikembangkan dengan cara salah satunya yaitu adanya penggunaan media.

\section{Saran}

Penelitian tentang kemampuan menulis teks naskah drama siswa kelas VIII SMP Negeri 18 Kota Bengkulu, diharapkan dapat memberikan masukkan saran kepada:

1. Bagi guru, khususnya guru Bahasa Indonesia agar menentukan dan menggunakan strategi, media, dan teknik yang tepat dalam memberikan pembelajaran, sehingga siswa menjadi termotivasi.

2. Bagi siswa, dalam pembelajaran ini dapat bermanfaat untuk meningkatkan kemampuan siswa dalam menulis teks naskah drama.

3. Bagi sekolah, merupakan masukan yang berupa saran atau kritik yang dapat membangun terhadap guru-guru 
dalam melaksanakan proses Putra, Bintang Angkasa. 2012. Drama Teori pembelajaran. dan Pementasan. Yogyakarta: PT Citra Aji Parama.

\section{DAFTAR PUSTAKA}

Waluyo, Herman J. 2002. Drama: Teori dan Pengajarannya. Yogyakarta:

Achmad, Sri Wintala. 2016. Menulis Kreatif Hanindita Graha Widya. Itu Gampang. Yogyakarta: Araska.

Dalman. 2013. Keterampilan Menulis. Jakarta: PT. Raja Grafindo Persada.

Yonny, Acep. 2014. Mahir Menulis Naskah Drama: Panduan bagi Pelajar. Yogyakarta: Suaka Media.

Tarigan, Henry Guntur. 2008. Menulis sebagai Keterampilan Berbahasa. Bandung: Angkasa. 